\title{
Young children and their conduct of everyday life
}

\section{Røn Larsen, Maja; Stanek, Anja Hvidtfeldt}

Published in:

Nordic Psychology (Online)

DOI:

10.1080/19012276.2015.1062256

Publication date:

2015

Document Version

Peer-review version

Citation for published version (APA):

Røn Larsen, M., \& Stanek, A. H. (2015). Young children and their conduct of everyday life. Nordic Psychology (Online), 67(3), 195-209. https://doi.org/10.1080/19012276.2015.1062256

\section{General rights}

Copyright and moral rights for the publications made accessible in the public portal are retained by the authors and/or other copyright owners and it is a condition of accessing publications that users recognise and abide by the legal requirements associated with these rights.

- Users may download and print one copy of any publication from the public portal for the purpose of private study or research.

- You may not further distribute the material or use it for any profit-making activity or commercial gain.

- You may freely distribute the URL identifying the publication in the public portal.

Take down policy

If you believe that this document breaches copyright please contact rucforsk@kb.dk providing details, and we will remove access to the work immediately and investigate your claim. 


\title{
Young Children and their Conduct of Everyday Life
}

\author{
Maja Røn Larsen, Roskilde University \& Anja Hvidtfeldt Stanek, University of Southern Denmark
}

\section{Abstract}

The article presents findings from a practice research project dealing with the everyday life of 0-2 year olds across family and different day-care settings. From a critical psychological perspective, it explores three related issues: Young children's conduct of everyday life in and across different institutional settings. Professional pedagogical work related to supporting children's conduct of everyday life, and finally the restricted political and bureaucratic conditions for exactly these forms of pedagogical practice. The article addresses the theoretical challenge of understanding children through their conduct of everyday life in the field of tension between being someone who is dependent on others, being taken care of and arranged for - and, at the same time, someone who is actively participating, arranging and contributing to the reproduction and change of the collective life conditions in the social practice of day-care. These compound processes include the professional's complex efforts to support the many children's personal conduct of everyday life in and across their different life arenas, involving ongoing situated and sensitive exploration of children's perspectives through observations, conversations and collaborative processes with the different children, colleagues, families in the day-care environment. However, at the same time, exactly these situated explorative processes tend to be unheeded as professional in the more explicit professional explanations of problems in day-care. Through a discussion of this apparent contradiction and the conditions for developing a more situated approach, the article aims to contribute to the current professional and political discussions about day-care practice for the youngest children.

Keywords: Conduct of Everyday Life, Children, Infants and Toddlers, Critical Psychology, Daycare, professionalism.

\section{Introduction}

The Scandinavian countries, and especially Denmark, have a long tradition of day-care for the youngest children. In Denmark, for example, $18 \%$ of children aged 0-12 months and $86 \%$ of children aged 12-24 months attend either public family day-care or day nursery (Haagensen, 2011). In recent decades, international studies of the OECD-countries have shown a general increasing participation rate for under-two-year-olds in out-of-home-day-care (OECD 2001). However, the amount of research on young children's day-care life still remains rather slim, as pointed out in international reviews of early childhood education (Broström 2010; Dalli et al 2011; Haavind 2011). Different scholars specifically point out a lack of knowledge about how these societal arrangements play into children's everyday lives and their processes of development and learning. In continuation of this, various research projects about professional pedagogical work with children identify a need for theoretical concepts for young children's perspectives in their everyday lives in order to support pedagogues' and child-minders' reflections of their own practice (Ahrenkiehl et al 2013; Højholt, Røn Larsen \& Stanek 2007).

In this article, we intend to respond to these challenges by exploring the way young children conduct their everyday life in and across different social situations in the home and in day-care among a range of different participants: parents, peers and professionals. The approach presented here is based in a critical psychological perspective with a background in a cultural historical 
tradition. From this standpoint, young children are explored as persons with intentions and engagements participating in a social world, where they are simultaneously determined by and determining their life conditions (ex. Fleer \& Hedegaard 2010; Hedegaard 2012; Højholt \& Kousholt 2015; Rogoff 2003). Within the critical psychological approach, the concept of conduct of everyday life has played a central part in the discussions of this dialectic relation, relating the processes of learning and development to the subject's concrete engagements in and arrangement of his/her everyday life (Dreier 2009; Juhl 2014, 2015; Chimirri 2013a). Holzkamp states: “... explicating a subject's situatedness within a scene of everyday life conduct provides the possibility of developing scientific concepts which, by integrating the world-in-its-concrete form, avoid their prevailing abstractness and emptiness. (...) "conduct of everyday life" is (...) the elementary form of human existence: There is no human being who is not situated within a scene of everyday life conduct" (Holzkamp, 2013a, s. 314). When trying to grasp the conduct of everyday life as the elementary form of human existence, it becomes relevant and important to know more about the ways in which young children actually handle their life in and across different institutional settings. It also becomes interesting to explore how, through their conduct of life, they at the same time develop their different personal ways of participating and contribute to developing different social practices through cooperation and conflict with other participants (Chimirri 2013a \& b, Højholt \& Kousholt 2015).

In the study upon which this article is based, we have investigated young children's everyday lives in the Danish day-care system for 0-2 year olds over a period of two years. Analysis of observations, interviews and discussions with the professionals indicates two rather contradictory tendencies:

1) That the children are widely dependent on the professional's possibilities of situated and collaborative exploration of the children's perspectives, possibilities of participation and personal conduct of everyday life.

2) That a very prevalent way to talk about problems with young children's day-care life among the professionals latches onto interpretations of the parents' ways of handling parenthood and the parent-child separation in the transition between home and day-care (Haavind 2011).

In general, our study indicates that a wide range of flexibility and situated decision-making are necessary in order to arrange the concrete life conditions for the children, and it shows that this conflictual and collaborative practice is present in many forms around young children. However, at the same time, these approaches seem to be unheeded as professional pedagogy, in favour of figures of understanding focusing on the appropriateness of parent's attitudes and their relations to the child. In this way, the situated explorative approaches are at risk of being neglected and undermined in future as a part of the acknowledged professional terminology. Furthermore, this focus on exploring 0-2 year-olds as persons with intentions, actively participating in and contributing to the construction of their social conditions, seems to be under pressure within the current professional and political debates about development of the professional work in day-care. In recent years there has been a tendency for raised demands for more control and more prior planning of activities in day-care. These demands have been anchored in more political discussions. On the one hand, it has played a central part in the discussions of how to develop the management strategies for controlling quality in day-care. On the other hand, one can also see traces of a more scholastic discussion of continuity in the educational system, where the ambitions 
of supporting the development of certain competencies in relation to preparing children for their future academic life in school has played an increasingly large part (Ahrenkiehl et al. 2013, Plum 2014). As we will outline, our research project indicates that there might be a downside in relation to professional support of children's conduct of everyday life associated with such a trend.

\section{The concept of conduct of everyday life.}

For some time now there has been focus on developing concepts for persons' conduct of everyday life. Until recently, the primary focus has been on the lives of adults. Lately however, there has been an increasing interest in developing both the theoretical and the empirical approach to children's conduct of everyday life (e.g. Chimirri 2013a \& b; Dreier 2008, 2011; Juhl 2014, 2015; Højholt \& Kousholt 2015).

Originally, Klaus Holzkamp developed the concept of conduct of everyday life in order to connect the processes of learning closer to people's everyday lives, their intentions and the way they arranged their lives through mutual social processes (Holzkamp 1995, 2005, 2013b and see also Chimirri 2014). In this way, he located the processes of learning as very closely related to the way people, as subjects, handle, organize and influence their actual lives in the world. Here learning is interlinked with the processes of navigating, adapting, influencing and contributing to everyday life. Learning and development is hereby connected to the intentionality of the subject (Højholt \& Røn Larsen 2014; Schwartz 2014, Stetsenko 2008).

What is central here is that the concept of conduct of everyday life helps to focus on "the subject in the world" as a subject making active efforts in organizing it's life in and across different settings among other participants, and through these processes, pursuing personal intentions and concerns and gaining influence in relation to common and shared everyday life routines (Holzkamp 1995, Dreier 2008). In this way, the active subject in a social practice (in this article the very young child) is seen as the centre of learning and development. One point here is that when taking the standpoint of the subject and investigating children's actions through their actual conduct of everyday life, we need to analyse processes of development and learning as deeply intertwined with the children's engagements in the everyday lives, as part of the social and conflictual processes of influencing, reproducing and changing the collective life conditions. Therefore, we argue, development needs to be studied through concrete investigations of what is at stake for the different participants in the situations. It becomes a central question to ask what kinds of engagements and intentions the children seem to be following in and across the different institutional settings in a collaborative and conflictual social practice with other participants. A fundamental aspect here is that the subject is understood as "always already involved in social practice" as Ole Dreier states it (Dreier 1999, p. 269).

We find it relevant to relate this approach to what Erica Burman identifies as a fundamental problem in developmental psychology, namely the tendency to separate the biological and the social in relation to studying children. From a standpoint within developmental psychology, Erica Burman problematizes the way development is often singled out and investigated as an isolated and individualized biological process that can be studied separately from other aspects of human life (ibid). She phrases this as the problem of "compartmentalizing" development to a naturalized process that can be divided up into different phases or functions (Burman 1994, p. 7). 
With inspiration from a broader critical psychological framework, we propose the concept of conduct of everyday life as an analytical possibility of "decompartmentalization", focusing on understanding development as an integrated part of the biological child developing in relation to the social world and, through this process, actively developing both herself and her life conditions, where neither the biological nor the social can be studied separately. This approach enables us to grasp development as intertwined with the child's conduct of everyday life, i.e. as a personal AND social (collective), conflictual process, where the social structuring is formed by the other participants and their conduct of life (Axel 2011; 2015; Chimirri 2013a, 2013b; Højholt \& Kousholt 2012; Juhl 2014).

Klaus Holzkamp raises a related critique to Burman's in his writings of what he phrases as "the colonization of childhood". Here Holzkamp questions what he calls "the developmental gaze". His claim is that within much of developmental psychology, "[c]hildhood is nothing other than a prestage to adulthood (...) The child is contrasted with the adult as "something unfinished"" (Holzkamp 2013a, p. 223), developing in a certain presupposed direction through e.g. different descriptions of phases or stages. Holzkamp argues that we need to study children from their firstperson-perspectives in relation to the concrete reality in which they are living. Referring to the ethnologist Florence Weiss, who studied latmul childhood in Papua New Guinea, Holzkamp continues: "Weiss makes it impressively clear how, only after she had overcome this "developmental gaze" could she find, in direct contact with the latmul children, access to their various forms of cultural life and social interaction, which were neither predictable from an adult viewpoint, nor could be sufficiently explained as a prestage to adulthood" (ibid. p. 223).

Taken alone, this quote might lead to a risk of "tribalization of children" as Gulløv calls it (Gulløv 2003; see also James, Jenks \& Prout 1998), i.e. the risk of studying children and their lives as something completely different and separate from the lives of adults. In relation to this, we find it necessary to enhance one of the critical psychological starting points: that subjects are always both determined by and the creator of their life-conditions (ex. Holzkamp 2005) and in this way emphasize how children always participate in and contribute to a world which they share with adults too, even though they occupy particular positions in this world. So here our interpretation of Holzkamp and Weiss escapes the risk of tribalization, when emphasizing children as subjects living a life that is conducted in a social world across different institutional settings and among other participants, and neither as objects for a certain developmental trajectory towards adulthood nor as free-floating exotic creatures of their own kind. This is where we argue that we need to understand development and learning as connected to children's participation in social practice, and as processes that must be studied as connected to their life conditions and their conduct of life in relation to these conditions in their everyday lives (Højholt \& Røn Larsen 2014; Stanek 2013). This leads us to consider children as participants, and to analyse how even very young children are conducting their lives as participants together with other people across different social practices, mainly at home and in a day-care institution.

\section{Methodological perspectives}

The endeavour of analysing children as subjects, conducting a concrete and situated everyday life among other people, leads to many methodological considerations. A central methodological point in the project is concerned with how to investigate the first-person-perspectives of young children, and how to look for their intentionality and engagements in the world. The children are approximately one year old when they start in day-care. Most of them have a quite limited 
verbalized language and ability to move around by themselves. However, analysing their collaborative and conflictual interplay in detail gives us the possibility to see them as subjects, negotiating and seeking influence on their life conditions using their actions: their sounds, utterances and bodies. This shows how even infants and toddlers exert influence on their life conditions, as provided in an institutional setting like the day-care institution, albeit they may not dispose over the verbal competences necessary for making their perspectives "heard" by either professionals or researchers.

The aim of a theoretical development of the understanding of children's conduct of everyday life among other people in certain institutional settings has been pursued by following the everyday life of infants and toddlers in their different types of institutionalized day-care in Denmark. Through participant observations in the day-care institutions and interviews with parents and professional caregivers, we have developed analytical child perspectives, in order to grasp the development of the children's participation as a constant and mutually developing relationship between the child's engagements and the institutional conditions, connected through the child's conduct of everyday life and his or her intentions of developing influence over their life conditions. The term "analytical" stresses that our access to the child's first-person-perspective will always be analytical, that we will never be able to "enter" the child's actual perspective (Kousholt 2011; Røn Larsen 2012; Sommer et al 2012). The analytical approach is connected to understanding the personal meanings of how "things hang together" from the perspective of the child (Dreier 2011) and trying to grasp the relations between the child's participation in different life contexts (Højholt 2012). In continuation of this approach, we have focused our interviews and observations on the exploration of the context for children's actions, trying to figure out what the children take part in and respond to. Having this as a central ambition in our methodological considerations, we conducted participant observations in day-care with the intention of "looking WITH" instead of "looking AT" children focussing on the contextual conditions for the subject. Instead of studying the children and their behaviour as isolated entities, the analytical focus was on what the children were focusing on, on what was happening around and in front of the children, observing what the children were looking at or turning towards or away from (see also Højholt \& Kousholt 2015; Juhl 2014, 2015; Røn Larsen 2011; Stanek 2011). In relation to developing analytical child perspectives, Charlotte Højholt comments:

"The curious thing is that the child as a person, to a greater extend becomes visible, even though, or perhaps even because we did not only focus on the person alone" (Højholt, 2005, p. 35, our translation).

Another reason for our research design stems from the considerations of the children's lives across different institutional settings. This is often phrased as "decentering" the analysis, stressing that what happens in one situation is often also connected to other situations and other contexts (Kousholt 2006; Røn Larsen 2011, Stanek 2011). Therefore, interviews with the adults around children provide us with different ways of figuring out how to understand and interpret what we observe. Learning about the children's conduct of their everyday lives was in this way dependent on relations between different sources of empirical material from a multifaceted research design. Located within a practice research tradition, we have been organizing continuous meetings with the professionals, where we have presented and discussed our observations, analyses and research results in order to, together with the professionals, investigate the grounds and conditions for what we have seen and heard (Højholt 2005; Højholt \& Kousholt 2012). These "practice 
research meetings" play an essential part when developing knowledge of dilemmas and often contradictory conditions in practice. In addition to this, we conducted interviews with the young children's parents both before and after the child's starting in day-care, asking questions about the child's everyday life at home and about the parent's expectations and impressions of the child's participation in the everyday life in day-care. We also interviewed the professionals in the different day-care settings and conducted participatory observations of the young children's (conduct of) everyday life in day-care.

\section{Analytical perspectives on young children's conduct of everyday life}

In the following we will present some of our empirical examples and the analytical outcome. We have focused on concrete situations from children's everyday lives in the process of "settling in", because challenges in these processes are very illustrative of the theoretical points of this article. On the one hand, it is very typical for the process of "settling in" that problems and difficulties are related to the parents and their, for the professionals, more or less appropriate ways of dealing with the child and the process of settling in and "letting go", as it is often termed. Therefore, the period of "settling in" is often discussed as a matter of the child and the family being able to "adapt" to the institutional setting. In this way, the professional explanations tend to reproduce the rather mechanistic understandings of the children that are criticized by Holzkamp, Burman and Weiss.

On the other hand, it is also during these processes that observations and discussions of the concrete ways of both parents, professionals and children of handling the settling-in process shows how children themselves both adapt and contribute to changing their life conditions. In the following, we present analysis of the ways in which young children actively conduct their lives by participating in conflictual, social practices among other participants such as parents, siblings, professionals and other children in day-care and through these processes they gain influence on their life conditions. In continuation of this analytical approach, we intend to contribute to the ongoing discussions of professionalism in relation to pedagogy around infants and toddlers within the day-care setting, pointing out the importance of understanding even very young children's perspectives and their ways of conducting their life.

\section{Settling in into day-care}

In Denmark there are primarily two types of day-care: the day nursery and the family day-care. In the day nursery, the children are organized in groups with approximately 12 children and 1-2 professionally trained pedagogues and 1-2 assistants present in shifting schedules during the day. This group is usually located in a larger institution with several other groups. The family day-care is occupied by child-minders, who are educated through training and supervision programmes offered by the local municipality. Normally, she (they tend to be women) takes care of 3-5 children in her private home. During the week, the child minders meet up with other child-minders and their children in organized playgroups or in each other's homes. Despite the different levels of formal education, in this paper the different personnel will be referred to as professionals. This is reasonable, since this article does not intend to delve into the many differences between the arrangements of day-care. Instead, we focus on the commonalities in the ways the everyday life of children involves collaborative processes between parents, professionals and peers (see also Andenæs 2011 for research on these processes as chains of care). The recurring motif that we wish to draw attention to is the interconnected processes of children conducting their life and the social practice of developing and reproducing the institutional structures in which they participate. 
In our study, we follow the children from just before they attend day-care. This means we visit the families before the children attend day-care, and interview the parents about the child's life in the family. When studying the child's trajectory of participation between the home and day-care, like in other studies, we notice the differences between home and day-care. This means that the child "settling in" is confronted with changes and shifts in relation to the rhythms and routines in their everyday life, between life at home with parents and sometimes siblings, and life in day-care with more participants, both professionals and peers (e.g. Dencik et al 1988; Sommer, Pramling Samuelsson \& Hundeide 2013). Often these changes or transitions are described as threats to the young children, and are addressed by explanations of the small child being unable to handle changes (For a critique, see Sommer 2005). In the following analysis we will address the changes differently, by focusing on the possibilities for learning and development in the shifting life conditions and possibilities of participation in and across the child's different life contexts (Dreier 2009).

The following consists of analytical examples from different children's processes of settling in. Let it be stated already now, that we do not think of them as representations of children's typical ways of reacting to, liking or disliking day-care. The children in our empirical material do not seem to act and react in "the same way" when they "settle in" to day-care. Some children just slip in and seem very happy to have an opportunity to participate in the life of a day-care environment from the first day. Others seem very unhappy and cry a lot and most children seem to do something in-between at the beginning. It is rarely easy to figure out what makes the difference. Instead, we focus on the changes and transitions as challenges and possibilities for the young children's conduct of everyday life, and we intend to illustrate how the children (and their fellow participants at home and in day-care) put a lot of effort into cooperating (and conflicting) about making the everyday life hang together for all the participants, and arranging for relevant possibilities of participation for the children.

In Denmark, it is common practice that the parents participate in the day-care together with the child during the first few days, followed up by days with short attendance for the child. This period is gradually increased through the first week or two. This is usually a period followed with attention and concerns from both parents and professionals. Children act and react in various ways when their parents start leaving them at day-care for several hours a day. A theme that becomes obvious throughout the empirical data, is that the actions and reactions are not only reserved for the newly started child, but also for the parents, the professional caregivers and the other children in daycare, who contribute to the situation with a newly started child in various ways.

In the project, the different professionals discuss the process of "settling in" as a challenging and vulnerable period that needs a high degree of sensitivity and flexibility in relation to the specific child and family. The professionals describe these periods as challenging, since the parents are both very observant and investigative, which sometimes leads to confrontations and negotiations over the child's welfare. The professionals also describe it as a period when the routines and rhythms in the day-care setting are challenged and rebuilt: a process that is both interesting and sometimes also exhausting. A child-minder explains: "All the time I keep searching to find what does THIS child want? What does s/he need?" In many ways the process of trying to understand the children is present in many aspects of the pedagogical work, but here she emphasizes it as a special situation, when it comes to getting to know the youngest children during the process of settling in. One of the professionals from the day nursery follows up: "For instance, on Mathilda's 
first day we put her at the end of the table when we had lunch. She kept on twisting and turning [The pedagogue shows with her body, how the child kept looking to the sides and over her shoulder]. And that made us think: Aha, this is not a good place for her to be seated because then she will not be able to orientate herself in the room. So she has to be moved to the other side of the table". For other children, it works just fine to be seated at the end of the table, so it is not possible to draw up settling-in-rules for how-to-do-practice. Instead, the professionals explain how important it is to look for all the small signs of what works for a specific child. A third child-minder explains: "You try, and perhaps sometimes you fail, but then you figure it out".

These are just a few examples of the many adjustments and changes that are made in the daycare setting in order for the children to settle in. The point is that "settling in" is not just a question of the child adapting to the institutional conditions. Rather, as will be argued later, it can be understood as a social practice of conflictual cooperation between the children, the parents, the professionals and the peers, which simultaneously both reforms and reproduces the institutional conditions of day-care.

\section{How young children are able to make their caregivers arrange and rearrange.}

In relation to the processes of settling in, questions about eating, drinking and sleeping are recurring themes. In relation to eating, drinking and sleeping, many small and large interventions are tested out in order to make it possible for the children to sleep for a suitable number of hours or to consume in what is negotiated to be the correct manner and a proper quantity of food and fluid by the parents, the professionals and eventually the healthcare personnel. Something that strikes us in the material is the way children are able to make their caregivers arrange and rearrange all sorts of things with their way of participating in the arrangements, whether it is giggling, shouting with joy, crying, eating or refusing to eat.

During the project, one of the child-minders receives a $91 / 2$ month old girl, Laura, who since infancy has been under medical observation for being underweight. The minder describes the process of Laura settling in as difficult, since the girl cries a lot and refuses to eat during the first couple of months in family day-care. The child-minder describes it as challenging that she can't figure out how to help the girl, and at the same time she feels guilty about the other children, because Laura takes up so much energy in the day-care.

"It is so hard to figure out what she wants. So in fact, I spend a lot of resources focusing on her. She's at my place eight hours a day, and it is not good when she doesn't eat."

At the beginning, Laura is still too young to walk, so she is very dependent of the child-minder moving her around and lifting her up. However, Laura often continues crying and squirms to get down when she is picked up. Observations show days with the child-minder picking Laura up, walking around, showing her things, putting her down again in the pram with her soother, where she seems most comfortable. While sitting in a large swing in the playground with Laura in her arms, the child-minder expresses her concerns:

"I don't really know what to do except to keep introducing her to different things. I can't really force her to do something that she doesn't want to. I can make her keep quiet with her soother, but I don't want that either..." Laura interrupts the conversation with loud cries and the child-minder gets up. "OH you didn't like the swing either?" she says to Laura, and carries her back to the pram again. 
Throughout this period, both the child-minder and the parents had concerns for Laura, who had stopped gaining weight. They invest a great deal of effort in trying to figure out what works for Laura. Every day they experiment with different kinds of food, different types of eating and sleeping schedules and different kinds of dining situations. They exchange information about Laura's nutrition and they discuss their different perspectives on their mutual challenges and successes with getting Laura to eat, both when they meet face-to-face in Laura's transition between day-care and the family, and through texting and send MMS's in the evening. Another child-minder tells us about a similar situation in relation to a boy's first days attending day-care:

"I had some experiences with a little boy, who would not eat or drink for the first few days, and I thought oh-oh... [She makes a worried face]"

She continues by saying that when the mother came to pick up the boy one of the afternoons in the beginning, she told her that he hadn't been eating very much. They reflected together on the specific arrangement around the meal situation.

"And then she [the mother] told me [the minder]: He is used to drinking from a transparent glass, and at home we have a tray that we put in front of the highchair because he is not able to sit and eat at the table. Afterwards, they brought me a highchair tray. I gave him a transparent glass and then he started drinking. Perhaps because now it was possible for him to see what was in it. That went on for about a week, and now he drinks from any cup or glass I give him."

Interview pieces like this tend to invite us to start guessing why it was important for this little boy to drink from a transparent glass for the first week attending day-care. However, in our analysis it is not really important why he initially would not drink from just any cup or glass. The central point of the analysis is that children, without verbalized language, attempt to influence the context and the life conditions in which they participate, and moreover that they become dependent on the caregivers around them as "detectives" of the signals they are sending. Looking across the material we find that when we study young children, their conduct of life does not seem to be a solitary project. They depend on adults in different positions - and they depend on cooperation between these adults (Andenæs 2011; Højholt, Røn Larsen \& Stanek 2014; Juhl 2014).

In relation to our study, we find it necessary to stress the mutuality of this conduct. Even very young children, such as the 11-month-old boy in the example, actively take part in relation to the adult's ways of arranging both their own and the children's lives. Another way to put this is that the children conduct their lives in very close cooperation with their adult caregivers, who respond to the way the children participate with their voices and bodies, ways of participation that are again dependent of the specific social practices in which they participate. As the child-minder concludes her story:

"And it is those signals that show me who he is and what he wants! With other children, I have just been able to give them any glass."

One might add here that it is not the "signals" in themselves that show the child-minder what to do. It is the cooperative exploration in collaboration with the children's parents, where they interpret the situation and together figure out how to support the children's attempts to understand and organize their new life situation (Juhl 2014). It is important to stress here, that these collaborative processes are not always as harmonious as it might seem in the previous examples. Because of the parents' 
and the professionals' different positions in the child's life, and their different accesses and kinds of knowledge, they do not always agree on how to interpret a situation and how to solve a problem. Nevertheless, our analysis points out how these conflictual collaborative processes seem to be at the heart of the efforts to support the child's personal conduct of an everyday life across the different settings. The example of the transparent glass could very easily be interpreted in ways where the focus is put on the "child's need" for different contexts to be the same, which actually doesn't seem to be the case when we look across our data. Instead, we see it as a process of arranging connections or links between children's different context's, providing them with possibilities to understand and grasp their new life conditions. In the specific example, we do not regard the glass or the tray-table as "objects of home". Rather, we consider them to be parts of a changing dinner practice developed in cooperation between the child, the parents and the professional - a practice that is developing in order to meet the demands of everyone. This also means that it is not a constant practice, worked out once and for all. In the example, we see that after a week, the child drinks from other cups and glasses as well. Instead, we regard it as an example of the process where new social practices and possibilities are developed through collaboration between different participants in the child's everyday life. By their exchange of knowledge from the different settings, the child's process of linking to already known life practices are supported. And here the children are deeply dependent on the situated flexibility and collaboration as a central part of the social practice of day-care. As we will see in the following examples, new children call for reorganizing the routines of everyday life in day-care.

\section{Collaboration between children, professionals, parents and peers}

Let us now return to Laura. As Laura starts to calm down in day-care, the child-minder explains how another side of "settling in" is connected to what she describes as "training Laura in different aspects of day-care life". Over the next couples of months, both she and the parents train Laura in walking by letting her walk between the hands of an adult. As time passes, Laura participates more and more willingly in this activity, at first by moving her feet forward, but later by also pulling the adult in the direction of toys, activities and peers.

The other children in day-care are also involved and they involve themselves in the process of Laura settling in. They respond to her crying, looking at her, stroking her hair or cheek and fetching things for her. At one time, when one of the other girls was having her diaper changed in the bathroom, the child-minder could hear Laura crying. When she returned to the room, one of the other children was trying to give her the soother. During an observation session, Laura sat in the pram while the child-minder was getting the children ready for sleep. The other children kept bringing her toy animals, throwing them up into the carriage. When the child minder came back in, she looked at the observer and asked: "Who put a complete zoo in here?" At other times though, the other children seemed annoyed by Laura and became involved in conflicts with her, pushing her around, squeezing in between her and the child-minder or taking her things away from her.

Through these cooperative and conflictual processes, Laura was slowly introduced to the routines of the day-care environment, to how and when to eat and how and when to sleep, in order for the child-minder to establish the possibilities of taking care of the other children too, and also to clean up and have a break during their nap-time. Also here, Laura both protested and cooperated. The child-minder tried to be flexible within the structured conditions of being alone with more than one child. She explained that during the day, there are times when she has to go and change diapers 
for one of the other children or arrange meals, where Laura is left to herself and the other children for a little while, i.e. that she can't be with Laura all of the time.

However, the process of settling in for Laura cannot solely be understood as a process of Laura "adapting" to the new setting. We must also see it as a process of the setting is continuously rearranged in order to meet both her and the other children's ways of participating. Through the observations and interviews over time, we see the daily routines and time schedules change in ways where some of the meals are consumed earlier and the sequence of the children being tucked in for their after-dinner nap is rearranged. The daily routines of going to the playground are also changed in order to fit Laura's need for an early nap.

In this way, the mutual and collaborative processes of allowing Laura to settle into day-care depends on a continuous collaborative process in which the structural conditions of the institutional arrangement of day-care are continuously challenged and rearranged. The point is that Laura conducts her everyday life in relation to many other participants and, through these processes; she also contributes to the development of the social practice of day-care. With her voice and her body, she engages in the social, conflictual practice of both reproducing, rearranging and changing the structural arrangements of the day-care setting, and thereby also influencing her life conditions and her possibilities of participation.

Six months later, Laura is eating full meals, both in day-care and at home. She walks and shows a huge interest in toys and in the other children. She continuously expands her possibilities of participation by influencing her possibilities and conditions in day-care, for example by negotiating and fighting over toys, trying to put herself in a position where she is relevant to the other children as a participant in play, reaching out for or refusing to accept certain things or meals and so on.

By presenting our analysis of the processes of "settling in", we wish to show how young children conduct their life through collaboration and conflicts with the other participants. By children's (often non-verbalised) agency, they actively contribute to developing and rearranging the conditions of the practice in which they participate. For example not eating and not sleeping tend to be common and powerful ways for children to negotiate and gain influence on their life conditions. When children refrain from eating, drinking or sleeping, their caregivers in our empirical material will often respond by collaborating and struggling about how to understand the child, and how to develop and arrange new ways to get the children to eat/drink/sleep. Active attempts of reaching out for or screaming to get something or someone can also be seen as central ways for children to gain influence on their life conditions and possibilities. At the same time, as a part of this dialectical process, we see children being guided and directed by the professionals in order to fit the routines and possibilities of day-care. At one time, a child-minder told us about the time when three young children attended her home simultaneously, all a bit insecure and whining. She explains how she had to teach them to come to her for comfort, because physically she wasn't able to be positioned in more than one place at a time. So in this specific situation, together with the children she developed some relevant possibilities of participation, which made her able to comfort them better.

According to the professionals, there are many things that have to be conducted collectively in order to make the everyday life of day-care work for the youngest children. However, all these daily events of arranging and rearranging the social practice around the children easily go on unnoticed and unheeded. These processes are not always easy to put it into words and concepts, and there 
are not always adequate conditions for such formulations within the current context of debate about professionalism in day-care.

\section{Summing up}

In our study focusing on children as subjects developing their personal conduct of life in and across the day-care setting and the family, we came to see the children as active participants among other participants using their bodies, their movements and their utterances in their ways of both acquiring new practices and at the same time influencing and changing them. In this way, professional efforts related to processes of settling in to day-care are also about cooperating with children as persons with personal preferences and about relations changing dialectically over time and in relation to the child's participation across the different contexts. In this way, the process of settling in is a demanding social practice of cooperation and conflict, exploration, changing and adjusting for all parties. It is a process that also contributes to the formation of the conditions in relation to which the child conducts his or her everyday life.

This is an aspect we wish to emphasize, because it makes clear how the children, parents and professional caregivers make up each other's conditions for participation and conduct of everyday life in ways that tend to be unheeded in the dominant professional terminologies. They are all dependent on each other in the social practices of everyday life, so no one conducts his or her everyday life alone. Conduct of everyday life is connected to a life among other people, which again implies that a young child develops his or her conduct of everyday life together with other children and together with his or her caregivers. "Settling in" to day-care is a social practice allowing and inviting children to develop their conduct of everyday life, not as a solitary project, but as both a very personal and a very social project of conflictual cooperation, depending also on the caregivers and their conditions, possibilities and limitations for cooperating with the children.

In relation to the ongoing political discussions regarding what kind of professionalism is required in the development of day-care, the analysis of our project suggests the requirement for special attention and a lot of time to get to know young children and their families in the process of settling in. It also requires a large degree of flexibility and readiness in order to arrange and rearrange the ongoing practice in relation to the constant professional reflections on the "situated detective work". Exploring the child's situation together with the parents, finding a transparent glass, rearranging dinner and napping-situations are very important parts of the reflexive pedagogical practice of supporting young children's possibilities for conducting their lives.

However, these are also issues that are described as problematic by the different professionals, since the flexibility of the conditions for the pedagogical practice is sometimes limited. The professionals describe a lack of concepts, a lack of respect and a lack of time for reflections and rearrangements of social practice among the youngest children.

A feature that is central in the current discussions about Danish day-care is the increasing demands of a more structured pedagogical plan for children's development and learning in the day-care institutions, and a concurrent increase in the bureaucratic demands of detailed descriptions and documentation of pedagogical planning. In these debates, pedagogical plans and structures tend to be related to practices outside day-care, for example the school and the bureaucratic practices, and therefore the focus on the situated cooperation and ongoing flexibility fade into the background. From the study of the youngest children's conduct of everyday life, we 
therefore identify a risk in the current situation around day-care. The tendencies in the ongoing political debates and trends in management around e.g. day-care curriculums, constitute restrictive conditions for the flexibility in day-care practice. The point is that the political tendencies form conditions for developing professionalism and pedagogical practice around the youngest children in ways that tend to restrict the possibilities for exactly the ongoing situated analysis and flexibility towards the concrete everyday life and intentions of the different children.

\section{References}

Ahrenkiel, A., Nielsen, B. S., Schmidt, C., Sommer, F. M., \& Warring, N. (2013) Daginstitutionen til hverdag: den upåagtede faglighed (Everyday in Day-Care - The Unheeded Professionalism]. Frederiksberg: Frydenlund Academic.

Andenæs, Agnes (2011). Chains of care: Organising the everyday life of young children attending day-care. Nordic Psychology 63(2), s 49- 67

Axel, E. (2011). Conflictual cooperation. Nordic Psychology (Online), 20(4), 56-78.

Axel, E. (2015). Design og byggeri som social praksis [Designing and Building as Social Practice], unpublished manuscript.

Broström, S., Nellemann Nielsen, S. \& Herring, H. (2010) Liv og læring i vuggestuen: målrettet pædagogisk praksis med 0-3-årige børn. [Life and Learning in the Nursery: Targeted Pedagogical Practice with 0-3 year olds]. Frederikshavn: Dafolo.

Burman, Erica (1994): Deconstructing Developmental Psychology. London: Routledge.

Chimirri, N. A. (2014) Investigating media artifacts with children: Conceptualizing a collaborative exploration of the sociomaterial conduct of everyday life. PhD.Thesis from Roskilde University, Roskilde

Chimirri, N. A. (2013a) Investigating Media Artefacts with Children - Conceptualizing a Collaborative Exploration of the Sociomaterial Conduct of Everyday Life. PhD Thesis, Roskilde University.

Chimirri, N. A. (2013b) Expanding the conduct of everyday life concept for psychological media research with children. In: A. Marvakis, J. Motzkau, D. Painter, R. Ruto-Korir, G. Sullivan, S. Triliva \& M.Wieser (Eds.) Doing Psychology under new conditions (pp. 355-364). Ontario: Captus.

Dalli, C., White, J., Rockel, J., Duhn, I., with Buchanan, E., Davidson, S., Ganly, S., Kus, L., \& Wang, B. (2011). Quality early childhood education for under-two-year-olds: What should it look like? A literature review. Ministry of Education.

Dencik, Lars., Bäckström, C., Larsson, E. (1988) Barnens två världar [The two worlds of the child]. ESSELTE Studium/ Almqvist\&Wiksell

Dreier, O. (1999) Participation, intercontextuality and Personal Trajectories. In: Mayers, W. et al (ed.) Challenges to Theoretical Psychology (pp. 269 - 277). Ontario: Captus Press

Dreier, O. (2008). Psychotherapy in everyday life. Learning in doing: Social, cognitive, \& computational perspectives. New York: Cambridge University Press. 
Dreier, O. (2009). The development of a Personal Conduct of Life in Childhood. In T. Teo, P. Stenner, A. Rutherford, E. Park \& C. Baerveldt (Eds), Varieties of Theoretical Psychology: International Philosophies and practical Concerns (pp. 175-183). Toronto: Captus Press Inc.

Dreier, O. (2011). Personality and the Conduct of Everyday Life. Nordic Psychology 63(2) 4-23

Gulløv, E. (2003). Et antropologisk blik på børnekultur [An anthropological gaze at children's culture]. In: B. Tufte, J. Kampmann \& M. Hassel (ed.) Børnekultur - et felt I bevægelse. København: Akademisk Forlag.

Fleer, M. \& Hedegaard, M. (2010). Children's Development as Participation in Everyday Practices Across Institutions. Mind, Culture and Activity, 17, 149 - 168

Haagensen, K. M. (Ed.) (2011). Nordic Statistical Yearbook (Vol. 49). Nord: Statistics Denmark.

Haavind, H. (2011). Loving and caring for small children: Contested issues for everyday practices. Nordic Psychology, 63(2), 24-48.

Hedegaard, M. (2012) Analyzing Children's Learning and development in Everyday Settings from a Cultural-Historical Approach. Mind, Culture and Activity 19:2, 127 - 138.

Holzkamp, K. (1995) Alltägliche Lebensführung als Subjektwissenschaftliches Grundkonzept. Das Argument, 37(6) 817 - 846.

Holzkamp, K. (2005) Mennesket som subjekt for videnskabelig metodik [Human as Subject for Scientific Methodology]. Nordiske Udkast, 33 (2) 5 - 34

Holzkamp, K. (2013a) Psychology: Social Self-understanding on the Reasons for Action in the Conduct of Everyday Life. pp. 233 - 341. In: Schraube, E. \& U. Osterkamp (Eds.), Psychology from the Standpoint of the Subject. Selected Writings of Klaus Holzkamp. New York: Palgrave Macmillian.

Holzkamp, K. (2013b) The Colonisation of Childhood: Psychological and Psychoanalytical Explanations of Human Development. pp. 210 - 232. In: Schraube, E. \& U. Osterkamp (Eds.), Psychology from the Standpoint of the Subject. Selected Writings of Klaus Holzkamp. New York: Palgrave Macmillan.

Højholt, C. (2005). Præsentation af praksisforskning [Presentation of Practice Research]. In C. Højholt (Ed.), Forældresamarbejde. Forskning i fællesskab (pp. 23-46). Gylling: Dansk Psykologisk Forlag.

Højholt, C. (2012). Communities of Children and Learning in School:: Children's Perspectives. In: Hedegaard, M, K. Aronsson, C. Højholt, \& O. Skjær Ulvik (red.), Children, Childhood and Everyday Life: Children's perspectives. (pp. 199 - 215). USA: Information Age Publishing

Højholt, C., \& Kousholt, D. (2012). Practice research. In T. Teo (Ed.), Encyclopedia of Critical Psychology. Berlin: Springer Science+Business Media B.V.

Højholt, C. \& Kousholt, D (2015), Children participating and developing agency in and across various social practices. In: Fleer, M. and B. v. Oers. Section: Child, families and communities in The International Handbook on Early Childhood Education. Netherlands: Springer. 
Højholt, C. \& Røn Larsen, M. (2014) Læring som et aspekt ved børns engagementer i hverdagslivet [Learning as an Aspect of Children's Engagements in Everyday Life]. I Aabro, C. (ed.) Læring i daginstituioner - et erobringsforsøg. Frederikshavn: Dafolo.

Højholt, C., Røn Larsen, M., \& Stanek, A. H. (2014). Børnefællesskaber - om de andre børns betydning: at arbejde med rummelighed og forældresamarbejde [Children's Communities the Importance of the other Children: Working with Cooperation with Parents and Inclusion]. Frederiksberg: Frydenlund Academic.

James, A., Jenks, C. \& Prout, A. (1998). Theorizing Childhood. Cambridge: Polity Press.

Juhl, P. (2014) På sporet af det gode børneliv: samfundets bekymring og børns perspektiver på problemer i hverdagslivet. [Tracking Down the Good Child Life - societal concerns and children's Perspectives on problems in everyday life]. PhD Thesis, Roskilde University.

Juhl, P. (2015) Toddlers pursuing Possibilities for Actions across Contexts: Nuancing the concept of Everyday Life. In: Dialogue and debate in the making og theoretical psychology: Proceedings of 15th Biennial conference of The International Society for Theoretical Psychology (ISTP) Ontario: Captus Press Inc.

Kousholt, D., (2006). Familieliv fra et børneperspektiv - fællesskaber i børns liv. [Family Life From a Children's Perspective - Communities in Children's Lives] PhD Thesis, Roskilde University.

OECD (2001) Starting Strong - Early Childhood Education and Care. Paris: OECD

Plum, M. (2014). Den pædagogiske faglighed i dokumentationens tidsalder: Læreplaner, dokumentation og styring på daginstitutionsområdet [Pedagogical Professionalism in the Era of Documentation]. København: Dafolo.

Rogoff, B. (2003). The Cultural Nature of Human Development. Oxford University Press, Oxford.

Røn Larsen, M. (2011). Samarbejde og strid om børn i vanskeligheder-organiseringer af specialindsatser i skolen [Cooperation and Conflict about Children in difficulties Organisation of Special Support in School]. PhD Thesis, Roskilde University.

Røn Larsen, M. (2012) A paradox of Inclusion - Administrative procedures and Children's Perspectives on Difficulties in School. In. Hedegaard, M. et al (ed.) Children, Childhood and Everyday Life - Children's Perspectives (pp. 143 - 160). Charlotte: Information Age Publishing.

Schwartz, I. (2014). Hverdagsliv og livsforløb. Tværprofessionelt samarbejde om støtte til børn og unges livsforelse. [Everyday Life and Lifestories. Interprofessional work on supporting children and youth conduct of life] Aarhus: Klim.

Sommer, D. (2005) Barndomspsykologi- udvikling i en forandret verden [Childhood Psychology Development in a Changed World]. København: Gyldendal Akademisk.

Sommer, D., Samuelsson, I. P., \& Hundeide, K. (2013). Early childhood care and education - A child perspective paradigm. European Early Childhood Education Research Journal, 21(4), 459-475.

Stanek, A. H. (2011). Børns fællesskaber og fællesskabernes betydning: studeret i indskolingen fra bornehave til 1. klasse og SFO [Children's Communities and the meanings of communities - 
studied in the transition from kindergarten to school and afterschool centre]. PhD Thesis, Roskilde University.

Stanek, A. H. (2013) Understanding Children's Learning as Connected to Social Life. In: Marvakis, A, Motzkau, J., Painter, D. Ruto-Koir, R. Sullivan, G., Triliva, S., Wieser, M. (ed.) Doing Psychology under New Conditions (365 - 373). Ontario: Captus press Inc.

Stetsenko, A. (2008) From Relational Ontology to Transformative Activist Stance on Development and Learning: Expanding Vygotsky's (CHAT) Project. Cultural Studies of Science Education 3:471-491. 